Zeszyty Naukowe Szkoły Głównej Gospodarstwa Wiejskiego w Warszawie Problemy Rolnictwa Światowego tom 17 (XXXII), zeszyt 1, 2017: 226-235

DOI: $10.22630 /$ PRS.2017.17.1.21

Agata $\dot{Z ̇ a k}^{1}$, Marek Zieliński

Instytut Ekonomiki Rolnictwa i Gospodarki Żywnościowej - Państwowy

Instytut Badawczy w Warszawie

\title{
Ocena funkcjonowania gospodarstw rolnych dotkniętych suszą rolniczą na tle gospodarstw pozostałych położonych na glebach słabych
}

\section{Comparison between the Function of Farms Affected by Agricultural Drought and Farms Situated on Low Quality Soils}

\begin{abstract}
Synopsis. Celem analiz było porównanie sytuacji ekonomicznej i możliwości rozwoju gospodarstw rolnych dotkniętych suszą rolniczą i gospodarstw pozostałych funkcjonujących na glebach słabych. Dla osiągnięcia zamierzonego celu wykorzystano dane $\mathrm{z}$ gospodarstw specjalizujących się $\mathrm{w}$ uprawach polowych, chowie krów mlecznych i z produkcją wielostronną, które nieprzerwanie prowadziły rachunkowość dla Polskiego FADN w latach 2012-2014 oraz dane z Systemu Monitoringu Suszy Rolniczej (SMSR) prowadzonego przez Instytut Uprawy, Nawożenia i Gleboznawstwa - Państwowy Instytut Badawczy w Puławach w latach 2012-2014. Stwierdzono, że gospodarstwa specjalizujące się w uprawach polowych dotknięte suszą rolniczą w porównaniu do analogicznych gospodarstw pozostałych miały zdecydowanie mniejszy dochód na 1 ha UR, aczkolwiek były jednak w stanie inwestować w majątek trwały na poziomie zapewniającym jego dodatnią stopę reprodukcji. W pozostałych dwóch grupach gospodarstw dotkniętych suszą rolniczą, które przynajmniej w części zajmowały się chowem zwierząt, wpływ suszy rolniczej na ich sytuację ekonomiczną był znacznie mniejszy.
\end{abstract}

Słowa kluczowe: susza rolnicza, gospodarstwa rolne, sytuacja ekonomiczna, możliwości rozwoju, metoda Propensity Score Matching

\begin{abstract}
The aim of this paper was to compare the economic situation and investment abilities of farms affected by agricultural drought and other farms situated on low quality soils. The study used empirical data from field farms, milk farms and mixed farms that had collected data from 2010 to 2012 for the Farm Accountancy Data Network (FADN). We also used data from the Monitoring of Agricultural Drought that was conducted by the Institute of Soil Science and Plant Cultivation-State Research Institute in years 2012-2014. It was found that field farms affected by agricultural drought in comparison to other farms had visibly lower family farm income per 1 ha of UAA. Nonetheless, they had a positive rate of capital reproduction. In the case of milk farms and mixed farms, the negative impact of agricultural droughts on their economic situation was lower.
\end{abstract}

Key words: agricultural drought, farms, economic situation, development abilities, method Propensity Score Matching

\footnotetext{
${ }^{1}$ dr, Zakład Ekonomiki Gospodarstw Rolnych, Instytut Ekonomiki Rolnictwa i Gospodarki Żywnościowej - PIB, ul. Świętokrzyska 20,00-002 Warszawa, e-mail: agata.zak@ierigz.waw.pl

${ }^{2}$ dr, Zakład Ekonomiki Gospodarstw Rolnych, Instytut Ekonomiki Rolnictwa i Gospodarki Żywnościowej - PIB, ul. Świętokrzyska 20,00-002 Warszawa, e-mail: marek.zielinski@ierigz.waw.pl
} 


\section{Wprowadzenie}

Postępujące zmiany klimatu w Polsce, Europie, jak i na całym świecie sprawiają, że dla gospodarstw rolnych ważnym wyzwaniem staje się konieczność adaptacji do występujących coraz częściej w produkcji rolniczej susz.

Polska znajduje się w strefie klimatu przejściowego umiarkowanego, z możliwością występowania susz. Zjawiska takie mają charakter anomalii atmosferycznej związanej z okresem bezopadowym lub z opadami mniejszymi od średnich. Ich częstości, czasu trwania i nasilenia nie można określić, a terminu wystappienia nie sposób przewidzieć.

W okresie suszy rolniczej ${ }^{3}$ wilgotność gleby jest niedostateczna do zaspokojenia potrzeb wodnych roślin i prowadzenia prawidłowej produkcji rolnej. Zjawisko to doprowadza do spadku wielkości i jakości plonów głównych roślin uprawnych, ale nie tylko. W sytuacji spadków plonów głównych występuje również obniżenie plonów ubocznych: słomy i pozostałych resztek pożniwnych, przyczyniając się do zmniejszenia produkcji biomasy jako źródła materii organicznej w glebie (Zieliński, 2015). Szans poprawy tej sytuacji upatrywać należałoby w powszechniejszym stosowaniu systemów nawadniania roślin uprawnych. W Polsce, powierzchnia nawadniana jest jednak niewielka i wynosi około 70 tys. ha (GUS, 2016). Przyczyn tego stanu szukać należy przede wszystkim w wysokich kosztach inwestycji i eksploatacji urządzeń nawadniających oraz często $\mathrm{w}$ ograniczonej dostępności zasobów wodnych do nawadniania. Warto pamiętać, że zasoby wodne w Polsce w przeliczeniu na 1 mieszkańca są trzykrotnie mniejsze w porównaniu do średniej dla Europy (Narodowy Program..., 2015).

Przyrodnicze warunki gospodarowania determinują uzyskane efekty ekonomiczne oraz zdolność do rozwoju gospodarstw rolnych. Gospodarstwa położone na glebach słabych mają mniejszą możliwość efektywnego ekonomicznie gospodarowania, szczególnie w rejonach dotkniętych suszą rolniczą (Zieliński, 2015, 2016). W Polsce problem ten jest ważny, gdyż przeciętny wskaźnik bonitacji gleb (WBG) wynosi 0,8 (GUS, 2012). Blisko $44 \%$ powierzchni użytków rolnych znajduje się w gospodarstwach rolnych funkcjonujących na glebach słabych (WBG do 0,7). Z tego około $19 \%$ tej powierzchni znajduje się w gospodarstwach rolnych o przeciętnym wskaźniku bonitacji do 0,4 , a około $25 \%$ w gospodarstwach rolnych o wskaźniku bonitacji 0,4 - 0,7. Co więcej, według P. Skłodowskiego i A. Bielskiej (2009) potencjał produkcyjny przeciętnego hektara gleb w Polsce odpowiada potencjałowi przeciętnych 0,6 ha gruntów ornych w pozostałych krajach Unii Europejskiej.

Celem analizy jest porównanie sytuacji ekonomicznej i możliwości rozwoju gospodarstw rolnych z uprawami polowymi, chowem krów mlecznych i z produkcją wielostronną dotkniętych suszą rolniczą oraz pozostałych położonych na glebach słabych, które nieprzerwanie prowadziły rachunkowość dla Polskiego FADN w latach 2012-2014.

\footnotetext{
${ }^{3}$ Susza rolnicza oznacza szkody spowodowane wystapieniem w dowolnym sześciodekadowym okresie od dnia 1 kwietnia do dnia 30 września klimatycznego bilansu wodnego (KBW) poniżej wartości krytycznej określonej dla poszczególnych gatunków roślin uprawnych i gleb (Ustawa z dnia 7 lipca 2005). Wskaźnik klimatycznego bilansu wodnego (KBW) stanowi różnicę między sumą opadu atmosferycznego a ewapotranspiracją potencjalną za dany okres (Doroszewski i in. 2012; Durło 2007; Mizak i in. 2011).
} 


\section{Metoda}

Analizą porównawczą objęto trzy grupy gospodarstw ze względu na typ produkcji, które położone były na glebach słabych $(\mathrm{WBG}=<0,7)$ i prowadziły nieprzerwanie rachunkowość dla Polskiego FADN w latach 2012-2014. Do grupy pierwszej zaliczono gospodarstwa $\mathrm{z}$ uprawami polowymi ${ }^{4}$. Grupa druga obejmowała gospodarstwa $\mathrm{z}$ chowem krów mlecznych, natomiast trzecia gospodarstwa $\mathrm{z}$ produkcją wielostronną (mieszaną ${ }^{5}$ ). Następnie wydzielone grupy gospodarstw podzielono dodatkowo na dwie podgrupy. Do pierwszej podgrupy zakwalifikowano gospodarstwa, w których zjawisko suszy rolniczej wystąpiło nieprzerwanie w okresie trzech lat. Natomiast do drugiej gospodarstwa niedotknięte tym zjawiskiem w analizowanym okresie. Przesłanką takiego podziału gospodarstw było przekonanie, iż dopiero okres trzyletni może wskazać jednoznacznie wpływ suszy na sytuację gospodarstw rolnych, pozwalając w dużym stopniu wyeliminować inne zmienne.

Do podgrupy gospodarstw dotkniętych suszą rolniczą zakwalifikowano gospodarstwa znajdujące się $\mathrm{w}$ gminach w województwie wielkopolskim i kujawsko-pomorskim, w których zjawisko to wystapiło nieprzerwanie w okresie trzech lat (rys. 1) ${ }^{6}$. W celu wydzielenia gmin dotkniętych suszą rolniczą skorzystano z wyników Systemu Monitoringu Suszy Rolniczej (SMSR) ${ }^{7}$ prowadzonego przez Instytut Uprawy, Nawożenia i Gleboznawstwa - Państwowy Instytut Badawczy w Puławach w latach 2012-2014.

W analizie porównawczej gospodarstw dotkniętych suszą rolniczą i pozostałych funkcjonujących na glebach słabych wykorzystano metodę Propensity Score Matching (PSM). Metoda ta miała na celu utworzenie grupy kontrolnej (gospodarstwa pozostałe), składającej się z jednostek (gospodarstw) w jak największym stopniu podobnych do tych, które znalazły się w grupie eksperymentalnej (gospodarstwa dotknięte suszą rolniczą) pod względem miary propensity score, którą skądinąd wyliczono w oparciu o modele logitowe i przy użyciu programu Statistica, w tym modułu obserwowane, przewidywane i reszty. Weryfikacja otrzymanych modeli logitowych polegała na sprawdzeniu czy spełniona jest istotność funkcji regresji oraz istotność współczynników regresji ${ }^{8}$.

Metoda PSM pozwoliła na dopasowanie do każdego gospodarstwa dotkniętego susza rolniczą pojedynczego gospodarstwa pozostałego, które miało ten sam typ produkcyjny oraz niemal identyczną powierzchnię użytków rolnych (ha), nakłady pracy w przeliczeniu

\footnotetext{
${ }^{4}$ Według metodyki Polskiego FADN gospodarstwa z uprawami polowymi obejmują gospodarstwa specjalizujące się w uprawie zbóż, roślin oleistych i wysokobiałkowych na nasiona oraz specjalizujące się w uprawie polowej różnych gatunków roślin.

${ }^{5}$ Według metodyki Polskiego FADN gospodarstwa z produkcją wielostronną obejmują gospodarstwa $\mathrm{z}$ mieszaną produkcją roślinną, zwierzęcą lub roślinno-zwierzęcą.

${ }^{6}$ Za gospodarstwa dotknięte suszą rolniczą uznano te, które znajdowały się w gminach, w których zjawisko to wystapiło, dla co najmniej jednego gatunku lub grupy roślin uprawnych i w co najmniej jednym z 13 sześciodekadowych okresów wegetacji roślin wydzielonych na potrzeby SMSR przez IUNG-PIB, w trzech latach objętych analizą.

${ }^{7}$ System ten został opracowany i wdrożony przez IUNG-PIB na wniosek MRiRW. Umocowaniem prawnym potrzeby monitoringu suszy jest Ustawa z dnia 7 lipca 2005 roku o ubezpieczeniu upraw rolnych i zwierzą gospodarskich i Ustawa z dnia 25 lipca 2008 roku o zmianie ustawy o ubezpieczeniu upraw rolnych i zwierząt gospodarskich oraz ustawy o krajowym systemie ewidencji producentów, ewidencji gospodarstw rolnych oraz ewidencji wniosków o przyznanie płatności (MRiRW, 2005, 2008).

${ }^{8}$ Metodę PSM wykorzystano m.in. w dokumencie pt. Investment support under Rural Development Policy (KE, 2014), Guidelines for the ex post evaluation of 2007-2013 RDPs (KE, 2014) oraz Ocena wplywu PROW 20072013 na rozwój gospodarczy Polski i konkurencyjność gospodarstw rolnych (Zieliński i inni, 2016).
} 
na 1 ha UR (godz./ha) i średnią wartość kapitału w przeliczeniu na 1 AWU (tys. zł/AWU). W tym celu wykorzystując program Statistica 12 wykonano trzy modele logitowe. Pierwszy model dotyczył gospodarstw z uprawami polowymi, drugi z chowem krów mlecznych, a trzeci z produkcją wielostronną. $\mathrm{W}$ modelach zmienną objaśnianą był fakt prowadzenia lub też nie prowadzenia przez gospodarstwo produkcji rolniczej na terenach dotkniętych suszą rolniczą. Zmienną tę potraktowano zatem jako zmienną binarna (dychotomiczna), która przyjmowała wartość jeden w przypadku, gdy gospodarstwo w latach 2012-2014 było dotknięte suszą rolniczą, natomiast zero kiedy gospodarstwo w tym okresie nie było dotknięte tym zjawiskiem. Zmiennymi objaśniającymi były natomiast zmienne reprezentujące potencjał produkcyjny gospodarstw (powierzchnia użytków rolnych, nakłady pracy $\mathrm{w}$ przeliczeniu na 1 ha UR oraz średnia wartość kapitału $\mathrm{w}$ przeliczeniu na 1 AWU).

W wyniku zastosowania modelowania logitowego uzyskano miary propensity score dla każdego gospodarstwa dotkniętego suszą rolniczą oraz dla każdego gospodarstwa pozostałego. Następnie wykorzystując metodę skupień (metoda najbliższego sąsiada) dokonano doboru dla każdego gospodarstwa dotkniętego suszą rolniczą gospodarstwa o najbliższej wartości propensity score.

Ostatecznie, analizie porównawczej gospodarstw z uprawami polowymi poddano 16 gospodarstw dotkniętych suszą rolniczą i 16 gospodarstw pozostałych. W grupie gospodarstw z chowem krów mlecznych analizą objęto 26 gospodarstw dotkniętych suszą rolniczą i 26 gospodarstw pozostałych, natomiast $w$ grupie gospodarstw z produkcją wielostronną 62 gospodarstw dotkniętych suszą rolniczą i 62 gospodarstw pozostałych.

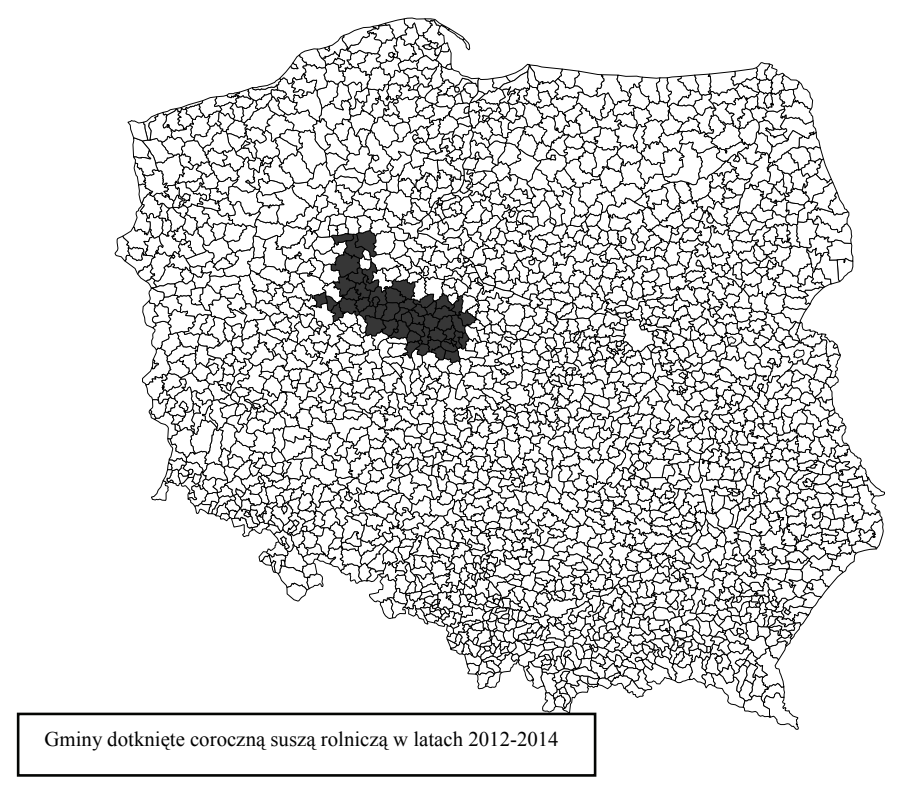

Rys. 1. Gminy dotknięte coroczną suszą rolniczą w Polsce w latach 2012-2014

Fig. 1. Communes affected by annual agricultural drought in Poland in years 2012-2014

Źródło: opracowanie własne na podstawie SMSR w latach 2012-2014. 
Do oceny porównawczej wyodrębnionych podgrup gospodarstw wykorzystano średnie roczne informacje dotyczące:

- potencjału produkcyjnego:

- powierzchni użytków rolnych (UR) wyrażonej w ha, na którą składają się: ziemia własna, ziemia dzierżawiona na jeden rok lub dłużej, ziemia użytkowana na zasadzie udziału w zbiorze z właścicielem, a także ugory i odłogi,

- nakłady pracy ogółem na 1 ha UR, obejmujące całkowite nakłady pracy ludzkiej w ramach działalności operacyjnej gospodarstwa rolnego określone w godz. ${ }^{9}$,

- Średniej wartości kapitału (tys. zł/AWU) w przeliczeniu na 1 AWU, ustalonej jako średnia arytmetyczna wartości kapitału pracującego na koniec i początek roku obrachunkowego. Na wartość tego kapitału składa się wartość: zwierząt, upraw trwałych, urządzeń melioracyjnych, budynków, maszyn i urządzeń oraz kapitału obrotowego,

- udziału kierowników gospodarstw z wykształceniem rolniczym zawodowym, średnim i wyższym (\%),

- organizacji produkcji:

- udziału gruntów ornych (GO) w użytkach rolnych UR (\%),

- udziału roślin jarych w gruntach ornych (\%),

- udziału zbóż w gruntach ornych (\%),

- udziału nawozów zielonych w gruntach ornych (\%),

- obsady zwierząt wyrażonej w sztukach przeliczeniowych na 1 ha gruntów ornych (LU/ha GO),

- efektów ekonomicznych i możliwości inwestycyjnych:

- dochodu z gospodarstwa rolnego na 1 ha UR (tys. zł/ha UR),

- stopy reprodukcji majątku trwałego (\%) - ustalonej jako iloraz wartości inwestycji netto wykonanych w danym roku w gospodarstwie do wartości środków trwałych występujących w tym gospodarstwie,

- stopy zadłużenia (\%) - ustalonej jako iloraz wartości kredytów krótkoi długoterminowych do średniej wartości kapitału.

\section{Wyniki badań}

W wyniku zastosowania metody PSM dla każdego gospodarstwa $\mathrm{z}$ uprawami polowymi, z chowem krów mlecznych i z produkcją wielostronną dotkniętych suszą rolniczą dobrano pojedyncze gospodarstwo pozostałe o analogicznym typie produkcyjnym oraz o niemal identycznej powierzchni użytków rolnych, nakładach pracy ogółem w przeliczeniu na 1 ha UR oraz średniej wartość kapitału w przeliczeniu na $1 \mathrm{AWU}^{10}$. W gospodarstwach z uprawami polowymi, z chowem krów mlecznych i z produkcją

\footnotetext{
9 Według metodyki Polskiego FADN jednej jednostce przeliczeniowej pracy wyrażonej w AWU (FWU) odpowiada 2120 godzin pracy (Polski FADN, 2014).

${ }^{10} \mathrm{~W}$ metodzie PSM wykorzystano modelowanie logitowe. Każdorazowo model logitowy został poddany weryfikacji. Weryfikacja modeli polegała na sprawdzeniu czy spełniona jest istotność funkcji regresji. Okazało się, że poziom p dla wartości testu $\chi^{2}$ (3) za każdym razem był mniejszy niż 0,05 , a to oznacza, że oszacowane modele stanowiły istotnie lepsze dopasowanie do danych niż model zerowy zawierający tylko wyraz wolny. Co więcej, dokonano weryfikacji istotności współczynników regresji. Dla wszystkich zmiennych poziom $\mathrm{p}<\alpha=0,05$, a to oznaczało, że parametry regresji były istotne statystycznie.
} 
wielostronną bez względu na fakt dotknięcia suszą rolniczą powierzchnia użytków rolnych wyniosła odpowiednio 44,5, 32,0 i 33,0 ha UR, nakłady pracy w przeliczeniu na 1 ha UR odpowiednio 100,0, 132,5 i 122,1 godz./ha, zaś średnia wartość kapitału w przeliczeniu na 1 AWU odpowiednio 361,4, 307,5 i 329,7 tys.zł/AWU (tabela 1).

Tabela 1. Potencjał produkcyjny gospodarstw dotkniętych suszą rolniczą i pozostałych w latach 2012-2014

Table 1. Production potential of farms affected by agricultural drought and other factors in years 2012-2014

\begin{tabular}{|c|c|c|c|}
\hline Wyszczególnienie & $\begin{array}{l}\text { z uprawami polowymi: } \\
\text { dotknięte pozostałe } \\
\text { suszą }\end{array}$ & $\begin{array}{l}\text { Gospodarstwa: } \\
\text { z chowem krów mlecznych: } \\
\text { dotknięte suszą pozostałe }\end{array}$ & $\begin{array}{l}\text { z produkcją wielostronną: } \\
\text { dotknięte } \\
\text { suszą }\end{array}$ \\
\hline $\begin{array}{l}\text { Powierzchnia } \\
\text { użytków rolnych (UR) }\end{array}$ & 44,5 & 32,0 & 33,0 \\
\hline $\begin{array}{l}\text { Nakłady pracy } \\
\text { ogółem (godz./ha UR) }\end{array}$ & 100,0 & 132,5 & 122,1 \\
\hline $\begin{array}{l}\text { Średnia wartość } \\
\text { kapitału (tys. } \\
\text { zł/AWU) }\end{array}$ & 361,4 & 307,5 & 329,7 \\
\hline
\end{tabular}

Źródło: opracowanie własne na podstawie danych Polskiego FADN z lat 2012-2014.

O potencjale produkcyjnym gospodarstwa rolnego może również decydować posiadane przez kierownika gospodarstwa wykształcenie rolnicze. Pod tym względem gospodarstwa dotknięte suszą rolniczą w porównaniu do gospodarstw pozostałych były w lepszej sytuacji. W gospodarstwach $\mathrm{z}$ uprawami polowymi dotkniętych suszą rolniczą w porównaniu do analogicznych gospodarstw pozostałych udział kierowników z wykształceniem rolniczym był bowiem większy o 6,2 punktu procentowego (p.p.), w gospodarstwach z chowem krów mlecznych o 3,8 p.p., a w gospodarstwach z produkcją wielostronną o 1,6 p.p (rys. 2). Nie należy wykluczyć, że wyższy poziom wykształcenia kierowników gospodarstw dotkniętych suszą rolniczą pozwolił im w pewnym stopniu łagodzić negatywne skutki susz rolniczych.

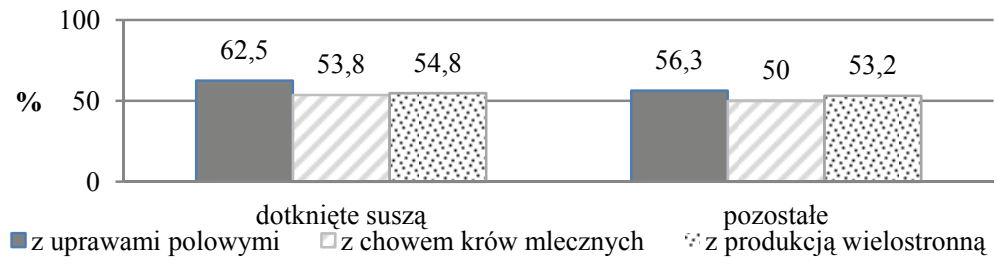

Rys. 2. Udział kierowników z wykształceniem rolniczym w gospodarstwach dotkniętych suszą rolniczą i pozostałych w latach 2012-2014

Fig. 2. Number of farms managed by farmers with agricultural education in farms affected by agricultural draughts and other factors in years 2012-2014

Źródło: jak w tabeli 1.

W tabeli 2 przedstawiono wybrane wskaźniki charakteryzujące organizację produkcji w poszczególnych podgrupach gospodarstw. Analiza pozwoliła wskazać kilka prawidłowości: 


\section{A. Żak, M. Zieliński}

- Udział gruntów ornych w użytkach rolnych nie wskazał na statystycznie istotne różnice między poszczególnymi podgrupami gospodarstw ${ }^{11}$. Niezależnie od przynależności do typu produkcyjnego $\mathrm{w}$ porównywanych podgrupach gospodarstw wskaźnik ten kształtował się na poziomie około $80,0 \%$.

- Uwage zwraca wyższy udział roślin jarych w strukturze zasiewów w gospodarstwach dotkniętych niedoborami wody opadowej. Zwłaszcza w podmiotach $\mathrm{z}$ uprawami polowymi, $\mathrm{w}$ których $\mathrm{W}$ porównaniu do analogicznych gospodarstw funkcjonujących $\mathrm{w}$ korzystniejszych warunkach, udział ten był o 6,3 p.p. wyższy i przekroczył $50 \%$. Sytuacja ta jest niepokojąca, gdyż rośliny jare charakteryzują się wyższą wrażliwością na niedobory wody opadowej w okresie wzrostu i rozwoju roślin.

- Udział zbóż w gruntach ornych najkorzystniej kształtował się w gospodarstwach $\mathrm{z}$ uprawami polowymi dotkniętych suszą rolniczą. Warto pamiętać, że wysoki udział zbóż prowadzi do zaburzenia równowagi biologicznej w środowisku rolniczym, a dominacja jednego gatunku zboża, czy też jednej odmiany w obrębie gatunku na danej przestrzeni nasila rozwój patogenów powodujących obniżkę plonu roślin uprawnych (Leszczyńska, 2010). W gospodarstwach tych niepokoi jednak brak uprawy na gruntach ornych nawozów zielonych na przyoranie oraz niewielka obsada zwierząt na 1 ha gruntów ornych. W efekcie gospodarstwa te mają ograniczone możliwości łagodzenia negatywnych skutków niedoborów wody opadowej $\mathrm{w}$ okresie wegetacji roślin. Wzrost udziału substancji organicznej w glebie poprawia nie tylko jej strukturę i zwiększa zawartość dostępnych dla roślin składników pokarmowych ale i zwiększa jej pojemność wodną.

Tabela 2. Wybrane wskaźniki charakteryzujące organizację produkcji gospodarstw dotkniętych suszą rolniczą i pozostałych w latach 2012-2014

Table 2. Selected indicators characterizing the organization of production for farms affected by agricultural drought and other factors in years 2012-2014

\begin{tabular}{|c|c|c|c|c|c|c|}
\hline Wyszczególnienie & $\begin{array}{c}\text { z uprawam } \\
\text { dotknięte } \\
\text { suszą }\end{array}$ & $\begin{array}{l}\text { polowymi: } \\
\text { pozostałe }\end{array}$ & $\begin{array}{r}\text { Go } \\
\text { chowem kr } \\
\text { dotknięte } \\
\text { suszą } \\
\end{array}$ & $\begin{array}{l}\text { arstwa: } \\
\text { nlecznych: } \\
\text { pozostałe }\end{array}$ & $\begin{array}{c}\text { z produkcja } \\
\text { dotknięte } \\
\text { suszą }\end{array}$ & $\begin{array}{l}\text { elostronną: } \\
\text { pozostałe }\end{array}$ \\
\hline $\begin{array}{l}\text { Udział gruntów ornych w } \\
\text { UR (\%) }\end{array}$ & 80,1 & 80,0 & 79,2 & 80,5 & 80,4 & 80,5 \\
\hline $\begin{array}{l}\text { Udział roślin jarych } \\
\text { w gruntach ornych }(\%)\end{array}$ & 50,2 & 43,9 & 43,2 & 35,1 & 38,6 & 35,9 \\
\hline $\begin{array}{l}\text { Udział zbóż w gruntach } \\
\text { ornych }(\%)\end{array}$ & 59,5 & 62,1 & 63,6 & 63,5 & 66,2 & 64,5 \\
\hline $\begin{array}{l}\text { Udział nawozów zielonych } \\
\text { w gruntach ornych }(\%)\end{array}$ & - & 10,1 & 11,9 & 12,0 & 10,9 & 12,4 \\
\hline $\begin{array}{l}\text { Obsada zwierząt na } 1 \text { ha } \\
\text { gruntów ornych }\end{array}$ & $0,1^{*}$ & $0,1^{*}$ & 1,9 & 1,9 & 1,2 & 1,3 \\
\hline
\end{tabular}

* w zaokragleniu do 1 miejsca po przecinku

Źródło: jak w tabeli 1.

\footnotetext{
11 W celu zbadania istotności różnic wykorzystano test nieparametryczny U Manna - Whitneya lub też parametryczne testy istotności dwóch średnich: test $t$ - Studenta lub też Cochrana - Coxa. Test nieparametryczny U Manna - Whitneya wykorzystano w sytuacji gdy rozkład porównywanej zmiennej odbiegał od rozkładu normalnego (test Shapiro - Wilka dla $\mathrm{p}<\alpha=0,05$ ). Natomiast parametryczne testy istotności dwóch średnich: test t - Studenta lub też Cochrana - Coxa w sytuacji, gdy rozkład ten miał cechy rozkładu normalnego (test Shapiro Wilka dla $\mathrm{p}>\alpha=0,05)($ Stanisz 2007a, 2007b).
} 
Jednym $\mathrm{z}$ podstawowych i najczęściej stosowanym kryterium oceny sytuacji ekonomicznej gospodarstw jest dochód. Gospodarstwa dotknięte suszą w porównaniu do analogicznych gospodarstw funkcjonujących w korzystnych warunkach wykazywały mniejsze dochody w przeliczeniu na 1 ha UR (rys. 3). Najmniej korzystnie kształtowały się te porównania $\mathrm{W}$ gospodarstwach $\mathrm{z}$ uprawami polowymi. W tej grupie różnica na niekorzyść gospodarstw dotkniętych suszą rolniczą wynosiła 42,4\%. Natomiast w gospodarstwach z produkcją wielostronną i chowem krów mlecznych różnice były znacznie mniejsze, wynosiły odpowiednio $20,7 \%$ i $4,2 \%$.

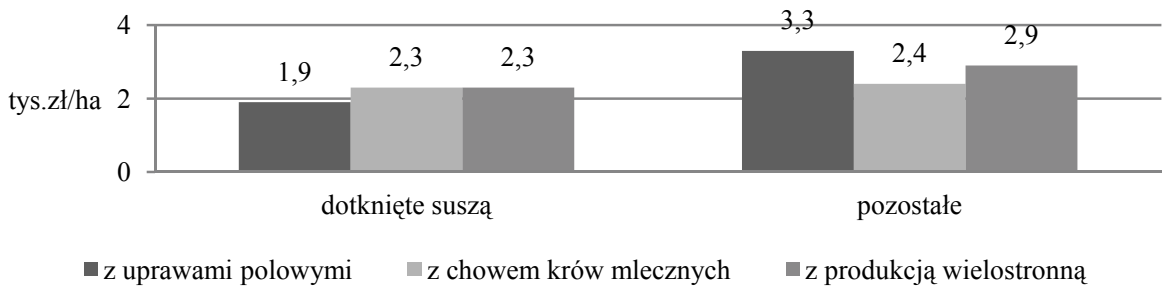

Rys. 3. Dochody w przeliczeniu na 1 ha UR (tys. zł/ha UR) w gospodarstwach dotkniętych suszą rolniczą i pozostałych w latach 2012-2014

Fig. 3. Income per 1 ha of UAA (thousand PLN/ha UAA) in farms affected by agricultural draughts and other factors in years 2012-2014

Źródło: jak w tabeli 1.

Tabela 3. Stopa reprodukcji majątku trwałego i zadłużenia gospodarstw dotkniętych suszą rolniczą i pozostałych w latach 2012-2014

Table 3. Reproduction rate of fixed capital and rate of debt for farms affected by agricultural droughts and other factors in years 2012-2014

\begin{tabular}{|c|c|c|c|c|c|c|}
\hline \multirow[t]{2}{*}{ Wyszczególnienie } & \multicolumn{4}{|c|}{$\begin{array}{l}\text { Gospodarstwa: } \\
\text { z chowem krów } \\
\text { mlecznych: }\end{array}$} & \multicolumn{2}{|c|}{ z produkcją wielostronną: } \\
\hline & $\begin{array}{l}\text { dotknięte } \\
\text { suszą }\end{array}$ & pozostałe & $\begin{array}{c}\text { dotknięte } \\
\text { suszą }\end{array}$ & pozostałe & $\begin{array}{c}\text { dotknięte } \\
\text { suszą }\end{array}$ & pozostałe \\
\hline $\begin{array}{l}\text { Stopa reprodukcji majątku } \\
\text { trwałego }(\%)\end{array}$ & 0,2 & 0,1 & 0,3 & 0,1 & 0,1 & 0,1 \\
\hline Stopa zadłużenia (\%) & 17,4 & 18,9 & 8,8 & 15,9 & 10,8 & 18,6 \\
\hline
\end{tabular}

Źródło: jak w tabeli 1.

Stopa reprodukcji majątku trwałego była na dodatnim poziomie we wszystkich gospodarstwach (tabela 3). Nieznacznie wyższą wartość tego wskaźnika zaobserwowano w gospodarstwach z uprawami polowymi i chowem krów mlecznych dotkniętych suszą rolniczą $\mathrm{w}$ porównaniu $\mathrm{z}$ analogicznymi gospodarstwami niedotkniętymi niedoborami wody opadowej. Oznacza to, że gospodarstwa dotknięte suszą rolniczą są również w stanie realizować inwestycje pozwalające im nie tylko zachować istniejący stan posiadania środków trwałych, ale i dalszy rozwój. Co ważne, inwestycje te przeprowadzają zarówno w oparciu o środki własne jak i obce. Warto jednak podkreślić, że różnice w stopie reprodukcji majątku trwałego w tak krótkim okresie objętym analizą mogą mieć charakter losowy. Kwestia inwestowania to bowiem proces długofalowy ze zróżnicowanym okresem wzrostu. 


\section{Podsumowanie i wnioski}

Problematyka niedoborów wody w rolnictwie ma coraz większe znaczenie w świetle zmian klimatu w Polsce, Europie, jak i na całym świecie. Jak wskazały przedstawione w artykule dane SMSR, w Polsce w latach 2012-2014 szczególne nasilenie zjawiska suszy rolniczej widoczne było na obszarze Niżu Polskiego, w części województwa wielkopolskiego oraz kujawsko-pomorskiego.

W opracowaniu dokonano oceny funkcjonowania gospodarstw nieprzerwanie dotkniętych tym zjawiskiem na tle gospodarstw pozostałych funkcjonujących na glebach słabych (WBG do 0,7), z podziałem na trzy typy produkcyjne (uprawy polowe, chów krów mlecznych oraz produkcja wielostronna).

Badania wskazały, że gospodarstwa specjalizujące się w uprawach polowych dotknięte suszą rolniczą w porównaniu do analogicznych gospodarstw pozostałych miały zdecydowanie mniejszy dochód na 1 ha UR, były jednak w badanym okresie w stanie nie tylko w pełni odtwarzać zużywający się w procesie produkcji majątek trwały, ale i dalej się rozwijać. W tym celu korzystały zarówno z kapitału własnego jak i obcego. Pozostałe dwie podgrupy gospodarstw dotknięte suszą, które przynajmniej w części zajmowały się chowem zwierząt, niedobory wody były w stanie rekompensować m.in. przez stosowanie odzwierzęcych nawozów naturalnych. Była to zapewne ważna przyczyna ograniczenia negatywnego wpływu suszy rolniczej na ich efekty ekonomiczne.

Przeprowadzona analiza nie wyczerpuje wszystkich wątków wpływających na szeroką problematykę negatywnych skutków oddziaływania niedoborów wody opadowej na efektywność gospodarstw rolnych i nie jest wolna od słabości statystycznej wynikającej z niewielkiej liczebności podgrup gospodarstw dotkniętych suszą rolniczą i pozostałych. Jednakże wskazuje, że w gospodarstwach rolnych na glebach słabych powtarzające się w okresie kilku lat niedobory wody opadowej zmniejszają ich dochody. Należy podkreślić, że susza bardziej oddziałuje na gospodarstwa bez produkcji zwierzęcej, które mają mniejszą możliwość zbilansowania potrzeb w zakresie nawożenia naturalnego.

\section{Literatura}

Doroszewski, A., Jadczyszyn, J., Kozyra, J., Pudełko, R., Stuczyński, T., Mizak, K., Łopatka, A., Koza, P., Górski, T., Wróblewska, E. (2012). Podstawy monitoringu suszy rolniczej. Woda - Środowisko - Obszary Wiejskie, ITP w Falentach, t. 12, z. 2.

Durło, G.,B. (2007). Klimatyczny Bilans Wodny okresów wegetacyjnych w Beskidach Zachodnich. Acta Agrophysica, $\mathrm{nr} 10$.

Guidelines for the ex post evaluation of 2007-2013 RDPs, Komisja Europejska, 2014.

Komisja Europejska (2014). Investment support under Rural Development Policy.

Leszczyńska, D. (2010). Stan i uwarunkowania uprawy mieszanek zbożowych w Polsce. Journal of Research and Applications in Agricultural Engineering, Vol. 55(4).

Mizak, K., Pudełko, R., Kozyra, J., Nieróbca, A., Doroszewski, A., Świtaj, Ł., Łopatka, A. (2011). Wyniki Monitoringu Suszy Rolniczej w uprawach pszenicy ozimej w Polsce w latach 2008-2010. WodaŚrodowisko-Obszary Wiejskie, t. 11, z. 2.

Narodowy Program Rozwoju Gospodarki Niskoemisyjnej (2015). Ministerstwo Gospodarki, projekt z dnia 4 sierpnia.

Rocznik Statystyczny Rolnictwa (2012). GUS, Warszawa.

Rocznik Statystyczny Rolnictwa (2016). GUS, Warszawa.

Skłodowski, P., Bielska, A. (2009). Właściwości i urodzajność gleb Polski podstawą kształtowania relacji rolnośrodowiskowych. Woda-Środowisko-Obszary Wiejskie, t. 9, z. 4(28). 
Stanisz, A. (2007). Przystępny kurs statystyki z zastosowaniem STATISTICA PL na przykładach z medycyny, Tom 2. Modele liniowe i nieliniowe, Statsoft, Kraków.

Stanisz, A. (2007). Przystępny kurs statystyki z zastosowaniem STATISTICA PL na przykładach z medycyny, Tom 3. Analizy wielowymiarowe, Statsoft, Kraków.

Ustawa z dnia 25 lipca 2008 roku o zmianie ustawy o ubezpieczeniu upraw rolnych i zwierząt gospodarskich oraz ustawy o krajowym systemie ewidencji producentów, ewidencji gospodarstw rolnych oraz ewidencji wniosków o przyznanie płatności (Dz.U. 2008. Nr 145 poz. 918, MRiRW).

Ustawa z dnia 7 lipca 2005 roku o ubezpieczeniu upraw rolnych i zwierząt gospodarskich (Dz.U. 2005. Nr 150 poz.1249 z późn.zm., MRiRW).

Wyniki standardowe 2013 uzyskane przez gospodarstwa rolne uczestniczące w Polskim FADN, Polski FADN, Warszawa, 2014.

Zieliński, M. (2015). Sytuacja ekonomiczna gospodarstw rolnych szczególnie zagrożonych wystąpieniem suszy rolniczej i gospodarstw pozostałych w latach 2006-2013 pr. zbior. pod red. W. Józwiaka pt. Przedsiębiorstwo i gospodarstwo rolne wobec zmian klimatu i polityki rolnej [1], Monografie Programu Wieloletniego 2015-2019, nr 16, IERiGŻ-PIB, Warszawa.

Zieliński, M. (2016). Ocena funkcjonowania gospodarstw rolnych z terenów ONW na tle gospodarstw pozostałych w latach 2006-2014, [w:] (red.) W. Józwiak Przedsiębiorstwo i gospodarstwo rolne wobec zmian klimatu i polityki rolnej (2). Monografie Programu Wieloletniego 2015-2019, nr 28, IERiGŻ-PIB, Warszawa.

Zieliński, M., Lorencowicz, E., Miller, A., Rumińska, P., Włodarczyk, A., Wojnicka-Sycz, E. (2016). Ocena wpływu PROW 2007-2013 na rozwój gospodarczy Polski i konkurencyjność gospodarstw rolnych, raport wykonany dla Ministerstwa Rolnictwa i Rozwoju Wsi w Warszawie. 